\title{
Students Self Regulated Learning in Numerical Methods Course using Computational Mathematics Teaching Materials
}

\author{
Abdul Baist $^{1^{*}}$, Ahmad Fadillah $^{1}$ and Dian Nopitasari ${ }^{1}$ \\ ${ }^{1}$ Department of Mathematics Education, Universitas Muhammadiyah Tangerang, Kota Tangerang, Indonesia \\ *Corresponding author: abdulbaist79@gmail.com | Phone Number: +6281316516255
}

\section{ARTICLE HISTORY}

Received : 7 December 2018

Revised : 12 February 2019

Accepted : 15 March 2019

\section{KEYWORDS}

Self regulated learning; Teaching materials;

\begin{abstract}
Self regulated learning is a learning system applied in universities. Therefore, self regulated learning is needed by students in taking courses in college. Based on the results of previous studies found that students self regulated learning is still low. This study aims to improve students self regulated learning by using computational mathematics teaching materials in numerical method courses. The method used in this study is quasi-experimental with non-equivalent control group design. Result of this study shows that increasing students self regulated learning that using computational mathematics teaching materials is not better than students that not using the teaching materials.
\end{abstract}

\section{INTRODUCTION}

The numerical method is a mathematical problem formulation technique that can be done with arithmetic operations. Completion of problems in numerical methods can not be separated from computer use today. The fabulous of a computer today can help to solve the problems to be more efficient and effective. (Chapra \& Canale, 2010)

The use of computers in solving problems in numerical methods requires computer programming skills. Sometimes, when the features available in a computer software cannot solve a numerical problem directly, skills in computer programming for the user is needed.

Students skills in computer programming are still low. It can be seen around $70 \%$ of students earn less than B (Baist $\&$ Pamungkas, 2017). One of the causes is the lack of examples given by lecturers. The cause shows how students depend on lecturers. This, indirectly, illustrates how student self regulated learning independence is still low.

Fadillah and Baist said that universities have a learning system that directs students to be regulated in learning (Fadillah \& Baist, 2017). Students self regulated learning is expected to bring them to success in their lectures. As Dörrenbächer and Perels said that self regulated learning is highly relevant for postsecondary academic success (Dörrenbächer \& Perels, 2016). While within the context of Turkish education, self-regulation is considered important aspect of a student's academic performance and success in classroom settings (Tanriseven, 2014). Self regulated learning eventually can reduce the dropout rate in college (Hu \& Driscoll, 2006).

Self regulated learning is the active participation of students in their own learning processes metacognitively, motivatively, and behaviorally (Zimmerman, 1989). The researchers emphasized three components in defining the concept of self regulation: 1) self-regulated learning includes students' metacognitive strategies for planning, monitoring and modifying their cognition, which refers to the awareness and control of thought processes; 2) students' management of their academic task efforts has been proposed as another important component; 3) the actual cognitive strategies that students use to learn the actual material (Peng, 2012).

Self-regulated learning strategies refer to actions and processes directed at acquisition of information or skills that involve agency, purpose, and instrumentality perceptions by learners (Zimmerman, 1990). In the process of self-regulated learning, learners need to set their learning goals, make their learning plans, choose their learning strategies, monitor their learning processes, evaluate their learning outcomes and suppress interference (Cheng, 2011).

The use of teaching materials that can help students develop their self regulated learning is certainly needed. Computational mathematics teaching materials are used to help students learn programming materials independently. The teaching materials have been created and designed beforehand to help students learn independently. It is expected that the teaching materials can develop student self regulated learning. This study aims to find out whether an increase in student self regulated learning using computational mathematics teaching materials is better than students who do not use the teaching materials.

\section{RESEARCH METHOD}

Quasi experiments are used as research methods used in this study. The non-equivalent control group design research design was selected in this study. Pretest and posttest were given to both groups, namely the experimental group and the control group. The treatment given to the experimental group is the 
learning of numerical methods using computational mathematics teaching materials.

The subjects of this study were students of the mathematics education program at the University of Muhammadiyah Tangerang. A total of 43 students were included in this study consisting of two classes with the first class as many as 23 students made as the experimental group and the second class as many as 20 students made as the control group.

Questionnaire of self regulated learning used in this study questionnaire made by Yandari et al (2018). The questionnaire was then modified to fit this study. The questionnaire results are then analyzed using inferential statistics. Normalized gain (N-Gain) was used in this study to determine the increase in student self regulated learning. The following table describes the interpretation of the N-Gain category (Fitriasari, Tanzimah, \& Sari, 2018).

Table 1. N-Gain category

\begin{tabular}{cc}
\hline N-Gain $(\mathrm{g})$ & Interpretation \\
\hline $\mathrm{g}>0.7$ & High \\
\hline $0.3<\mathrm{g} \leq 0.7$ & Medium \\
\hline $\mathrm{g} \leq 0.3$ & Low \\
\hline
\end{tabular}

\section{RESULT AND ANALYSIS}

\subsection{Students Self Regulated Learning}

\subsubsection{Initial Score of Students Self Regulated Learning}

Self regulated Learning questionnaire was given to the experimental group before being given treatment and control groups to determine the initial score of student self regulated learning.

Table 2. Initial Score of Students Self Regulated Learning

\begin{tabular}{|c|c|c|c|c|c|}
\hline \multirow{2}{*}{ Group } & \multirow{2}{*}{$\mathrm{N}$} & \multicolumn{2}{|c|}{ Score } & \multirow[t]{2}{*}{ Mean } & \multirow{2}{*}{$\begin{array}{l}\text { Standard } \\
\text { Deviation }\end{array}$} \\
\hline & & Min & $\operatorname{Max}$ & & \\
\hline Experiment & 23 & 57.50 & 82.00 & $\begin{array}{l}65.7 \\
2\end{array}$ & 5.73 \\
\hline Control & 20 & 48.50 & 73.50 & $\begin{array}{l}63.2 \\
8\end{array}$ & 7.17 \\
\hline
\end{tabular}

Before testing the mean differences using the t-test, the normality and homogeneity tests of the data were first tested. Following are the results of testing the normality and homogeneity summarized in the following table.

Table 3. Normality Test for Initial Score

\begin{tabular}{cccc}
\hline \multirow{2}{*}{ Group } & \multirow{2}{*}{} & \multicolumn{2}{c}{ Kolmogorov-Smirnov } \\
\cline { 3 - 4 } & & Statistic & Sig \\
\hline Experiment & 23 & 0.098 & 0.200 \\
Control & 20 & 0.157 & 0.200 \\
\hline
\end{tabular}

Table 3 shows that the value of Sig from the experimental group and the control group is 0.200 . Because the value of Sig > 0.05 , the data is normally distributed.
Table 4. Homogeneity Test for Initial Score

\begin{tabular}{llcc}
\hline Group & N & Levene Statistic & Sig \\
\hline Experiment & 23 & 0.706 & 0.406 \\
Control & 20 & & \\
\hline
\end{tabular}

Meanwhile the results of homogeneity testing in table 4 obtained the Sig value of 0.406. Because the value of $\mathrm{Sig}>0.05$, the data is homogeneous.

The initial data obtained shows that the data spreads normally and homogeneously. Therefore, testing the mean difference using the t-test can be done. Following are the results of the test.

Table 5. T-Test for Initial Score

\begin{tabular}{|c|c|c|c|}
\hline Group & $\mathrm{N}$ & $\mathrm{df}$ & Sig (2-tailed) \\
\hline Experiment & 23 & \multirow{2}{*}{41} & \multirow{2}{*}{0.222} \\
\hline Control & 20 & & \\
\hline
\end{tabular}

The test results using the t-test in table 5 obtained the Sig (2-tailed) value of 0.222 . Because the value of Sig (2-tailed) > 0.05 , there is no difference. This means that there is no significant difference between the experimental group and the control group.

\subsubsection{Final Score of Students Self Regulated Learning}

Self regulated learning questionnaire was given back to the experimental group after being given treatment. Likewise, for the control group, a Self regulated learning questionnaire was given. The following is the final score of students self regulated learning.

Table 6. Final Score of Students Self Regulated Learning

\begin{tabular}{|c|c|c|c|c|c|}
\hline \multirow[b]{2}{*}{ Group } & \multirow[b]{2}{*}{$\mathrm{N}$} & \multicolumn{2}{|c|}{ Score } & \multirow[t]{2}{*}{ Mean } & \multirow{2}{*}{$\begin{array}{c}\text { Standard } \\
\text { Deviatio } \\
\mathrm{n}\end{array}$} \\
\hline & & Min & $\operatorname{Max}$ & & \\
\hline Experiment & 23 & 61.50 & 82.00 & 68.52 & 4.76 \\
\hline Control & 20 & 48.50 & 73.50 & 65.15 & 4.37 \\
\hline
\end{tabular}

Table 6 shows the final score of students self regulated learning. It is seen that the average score of the experimental group is higher than the control group with standard deviations that are not much different. Statistical testing needs to be done to prove the difference.

Table 7. Normality Test for Final Score

\begin{tabular}{cccc}
\hline \multirow{2}{*}{ Group } & \multirow{2}{*}{$\mathrm{N}$} & \multicolumn{2}{c}{ Kolmogorov-Smirnov } \\
\cline { 3 - 4 } & 23 & Statistic & Sig \\
\hline Experiment & 20 & 0.154 & 0.167 \\
Control & 20.104 & 0.200 \\
\hline
\end{tabular}

Table 7 shows how the experimental group and the control group spread normally. This can be seen in the Sig value of the experimental group and the control group respectively 0.167 and 0.200 . Both value of Sig $>0.05$ then the data of the two groups is normally distributed.

Table 8. Homogeneity Test for Final Score 


\begin{tabular}{cccc}
\hline Group & $\mathrm{N}$ & Levene Statistic & Sig \\
\hline Experiment & 23 & 0.000 & \multirow{2}{*}{1.000} \\
Control & 20 & & \\
\hline
\end{tabular}

The homogeneity test results in table 8 show that the value of Sig is 1,000 . It can be concluded that the final score data of both groups is homogeneous because the value of Sig $>0.05$.

The final score of students self regulated learning shows normally distributed and homogeneous. The next step is to test the mean differences between the two groups. The following tests the differences in mean data using t-test.

Table 9. T-Test for Final Score

\begin{tabular}{cccc}
\hline Group & $\mathrm{N}$ & $\mathrm{df}$ & Sig (2-tailed) \\
\hline Experiment & 23 & \multirow{2}{*}{41} & 0.021 \\
Control & 20 & & \\
\hline
\end{tabular}

The results of the mean difference test using the t-test can be seen in table 9. Sig (2-tailed) values are obtained at 0.021 . Because the value of Sig $(2$-tailed $)<0.05$, there are differences in the two groups. This means that there are significant differences in the two groups.

\subsubsection{N-Gain of Students Self Regulated Learning}

Increasing students self regulated learning is obtained by calculating $\mathrm{N}$-Gain by using the initial score and the final score of students self regulated learning.

Table 10. N-Gain Score

\begin{tabular}{cccccc}
\hline \multirow{2}{*}{ Group } & \multirow{2}{*}{$\mathrm{N}$} & \multicolumn{2}{c}{ N-Gain } & \multirow{2}{*}{ Mean } & $\begin{array}{c}\text { Standard } \\
\text { Deviation }\end{array}$ \\
\cline { 3 - 4 } & & Min & Max & & 0.09 \\
Experiment & 23 & -0.090 & 0.25 & 0.075 & 0.09 \\
Control & 20 & -0.045 & 0.39 & 0.019 & 0.21 \\
\hline
\end{tabular}

Table 10 shows that the N-Gain mean of the experimental group is 0.075 with standard deviation 0.09 while the control group is 0.019 with standard deviation 0.21 . It was seen that the N-Gain mean of the experimental group was higher than the control group. But this does not mean that the increase in the experimental group is better than the control group. Further testing phase is needed to answer it.

The hypothesis proposed in this study is an increase in students self regulated learning who use computational mathematics teaching materials better than students who do not use these teaching materials. Prerequisite tests are needed to test the hypothesis. Normality and homogeneity tests are used to determine the test that will be used in testing the hypothesis.

Table 11. Normality Test for N-Gain Score

\begin{tabular}{cccc}
\hline \multirow{2}{*}{ Group } & \multirow{2}{*}{} & \multicolumn{2}{c}{ Kolmogorov-Smirnov } \\
\cline { 3 - 4 } & & Statistic & Sig \\
\hline Experiment & 23 & 0.179 & 0.055 \\
Control & 20 & 0.086 & 0.200 \\
\hline
\end{tabular}

The results of normality testing showed that the experimental group and the control group had a normal distribution. It can be seen in table 11 that the value of Sig in the experimental group is 0.055 and the control group is 0.200 .
Because the value of $\mathrm{Sig}>0.05$, the data is normally distributed.

Table 12. Homogeneity Test for N-Gain Score

\begin{tabular}{cccc}
\hline Group & N & Levene Statistic & Sig \\
\hline Experiment & 23 & 9.793 & \multirow{2}{*}{0.003} \\
Control & 20 & & \\
\hline
\end{tabular}

Meanwhile in table 12 it can be seen the data is not homogeneous. Sig value obtained is 0.003 . Because the value of Sig $<0.05$, the data is not homogeneous. Therefore, the N-Gain score for the experimental group and the control group are normally distributed but not homogeneous.

The hypothesis test used in this study is the Mann-Whitney $\mathrm{U}$ test. The following is the calculation of the Mann-Whitney $\mathrm{U}$ test.

Table 13. Mann-Whitney U for N-Gain Score

\begin{tabular}{cccc}
\hline Group & $\mathrm{N}$ & Mann-Whitney U & Sig \\
\hline Experiment & 23 & -1.218 & 0.228 \\
Control & 20 & 0.22 & \\
\hline
\end{tabular}

The results of the calculation of the Mann-Whitney $U$ test in table 13 obtained the Sig value of 0.228 . This means that the value of $\mathrm{Sig}>0.05$ so that there is no difference in the N-Gain score between the experimental group and the control group.

The results of this test indicate that the increase achieved by the experimental group is no better than the increase achieved by the control group. Although in table 10 it is seen that the average increase achieved by the experimental group is higher than the control group. Therefore, it can be concluded that the improvement of students' self regulated learning that using computational mathematics teaching materials is no better than students who do not use these teaching materials.

Teaching materials created with the aim of helping students achieve learning goals (Arsanti, 2018; Hartono \& Puspitasari, 2013; Muqodas, Sumardi, \& Berman, 2015). Guntur, Muchyidin, \& Winarso (2017) revealed that the materials have an impact on students' self regulated learning. Some research findings get that learning materials can increase students' self regulated learning. Like research conducted by Rosdiana, Sapri, \& Sahono (2017), the materials that evolve can increase students' self regulated learning. Meanwhile, the findings of Sari, Sonjaya, \& Anwar (2016) show that the materials have been able to improve students' self regulated learning, as shown by the value of N-Gain, which amounts to $0.50[18]$.

Some of the research findings mentioned above show that teaching materials can influence student learning and increase their self regulated learning. While in the study the increased students' self regulated learning that is achieved by the group who use computational mathematics materials (experimental group) is not better than a group of students who did not use these materials (control group). However, based on table 6 and table 2 , it is clear, that the average increase in the experimental group, i.e. 2.80, is higher than the average increase in the control group, which amounted to 1.87 . Beside that, based on table 10 , the average of $\mathrm{N}$-Gain achieved by experimental group, i.e. from 0075, which is higher than the average of N-Gain achieved by the control group, i.e. from 0.019. This has meaning that the teaching materials of computational mathematics can increase the students' self regulated learning. 


\section{CONCLUSION}

Based on the preliminary description and the result and discussion above, it can be concluded that the improvement of students' self regulated learning that using computational mathematics teaching materials is no better than students who do not use the teaching materials. Even so, the use of teaching materials has the potential to increase the students' self regulated learning.

\section{REFERENCES}

Arsanti, M. (2018). Pengembangan Bahan Ajar Mata Kuliah Penulisan Kreatif Bermuatan Nilai-Nilai Pendidikan Karakter Religius bagi Mahasiswa Prodi PBSI, FKIP, UNISSULA. Kredo: Jurnal Ilmiah dan Sastra, Vol. 1 No. 2 April 2018, 71-90. Retrieved from http://jurnal.umk.ac.id/index.php/kredo/article/view/21 07

Baist, A., \& Pamungkas, A., S. (2017). Analysis of Student Difficulties in Computer Programming. Volt Jurnal Ilmiah Pendidikan Elektro. Volume 2(2), pp: 81-92. Retrieved from http://jurnal.untirta.ac.id/index.php/VOLT/article/view/ 2211

Chapra, S. C., \& Canale, R. P. (2010). Numerical Methods for Engineers (pp. 3). McGraw-Hill.

Cheng, E. C. K. (2011). The Role of Self-regulated Learning in Enhancing Learning Performance. The International Journal of Research and Review, Volume 6 Issue 1, March 2011, 1-16. Retrieved from https://pdfs.semanticscholar.org/f70a/ff8f07bfae51e47dc 51e5675853987f19325.pdf

Dörrenbächer, L., Perels, F. (2016). Self-Regulated Learning Profiles in College Students: Their Relationship to Achievement, Personality, and the Effectiveness of an Intervention to Foster Self-Regulated Learning. Learning and Individual Differences 51 (2016) 229-241. Retrieved from

https://www.sciencedirect.com/science/article/pii/S1041 608016302175

Fadillah, A., \& Baist, A. (2017). Hubungan Motivasi dan Perilaku Terhadap Hasil Belajar Mata Kuliah Matematika Ekonomi. Prima Jurnal Pendidikan Matematika. Volume 1(1), pp: 43-48. Retrieved from http://jurnal.umt.ac.id/index.php/prima/article/view/25 3

Fitriasari, P., Tanzimah, dan Sari, N. (2018). Kemandirian Belajar Mahasiswa Melalui Blended Learning pada Mata Kuliah Metode Numerik. Jurnal Elemen. Vol. 4 No. 1, Januari 2018, hal. 1 - 8. Retrieved from http://e-journal.hamzanwadi.ac.id/index.php/jel/article/v iew/439

Guntur, M., Muchyidin, A., \& Winarso, W. (2017). Pengaruh Penggunaan Bahan Ajar Matematika Bersuplemen Komik Terhadap Kemandirian Belajar Siswa. EduMa, Vol. 6 No. 1 Juli 2017, 43-51. Retrieved from http://syekhnurjati.ac.id/jurnal/index.php/eduma/article /view/ 1667

Hartono, Y. \& Puspitasari, E. (2013). Pengembangan Bahan Ajar Mata Kuliah Sejarah Madiun Berbasis Kemandirian Belajar Mahasiswa. Agastya: Jurnal Sejarah dan Pembelajarannya, Vol. 3, No. 2, 49-68. Retrieved from http://e-journal.unipma.ac.id/index.php/JA/article/view/ 1465
Hu H., Driscoll, M. (2009). Self-Regulated Learning (SRL) in Community College Student Success. Presented at The Annual Convention of the AECT: 2009 Annual Proceedings-Louisville: (Vol. 1, pp.182-186). Retrieved from https://members.aect.org/pdf/Proceedings/proceedings09 /2009/09_25.pdf

Muqodas, R. Z., Sumardi, K., \& Berman, E.T. 2015. Desain dan Pembuatan Bahan Ajar Berdasarkan Pendekatan Saintifik pada Mata Pelajaran Sistem dan Instalasi Refrigerasi. Journal of Mechanical Engineering Education, Vol. 2, No. 1, Juni 2015, 106-115. Retrieved from http://ejournal.upi.edu/index.php/jmee/article/view/116 0

Peng, C. (2012). Self-Regulated Learning Behavior of College Students of Science and Their Academic Achievement. Physics Procedia 33 (2012) 1446-1450. Retrieved from https://core.ac.uk/download/pdf/82585106.pdf

Rosdiana, Sapri, J., \& Sahono, B. (2017). Pengembangan Modul Akuntansi untuk Meningkatkan Kemandirian dan Prestasi Belajar Siswa Kelas XII SMAN di Kota Bengkulu. DIADIK: Jurnal Ilmiah Teknologi Pendidikan, 7(2), 2017, 78-86. Retrieved from https://ejournal.unib.ac.id/index.php/diadik/article/view /3686

Sari, I., Sonjaya, Y., \& Anwar, S. (2016). Penggunaan Bahan Ajar Hasil Terjemahan untuk Meningkatkan Pemahaman Konsep dan Kemandirian Belajar. Educhemia (Jurnal Kimia dan Pendidikan), Vol.1, No.1, Januari 2016, 36-49. Retrieved from http://jurnal.untirta.ac.id/index.php/EduChemia/article/ view/438/322

Tanriseven, I. (2014). A Tool That Can Be Effective in the Self-regulated Learning of Pre-service Teachers: The Mind Map. Australian Journal of Teacher Education, Volume 39 Issue $\quad 1$ 65-80. Retrieved from https:/ / files.eric.ed.gov/fulltext/EJ 1016476.pdf

Yandari, I. A. V., Nindiasari, H., Khaerunnisa, E., Pamungkas, A. S., Karso, dan Nurjanah. (2018). Self-Regulated Learning in Designing Explorative Learning Tools Among Mathematics Pre-service Teachers through Explorative Module. SHS Web of Conferences 42, 00106 (2018). Retrieved from https://www.shs-conferences.org/articles/shsconf/abs/2 018/03/shsconf_gctale2018_00106/shsconf_gctale2018_0 0106.html

Zimmerman, B. J. (1989). A Social Cognitive View of Self-Regulated Academic Learning. Journal of Educational Psychology, 0022-0663, September 1, 1989, Vol. 81, Issue 3. Retrieved

from http://citeseerx.ist.psu.edu/viewdoc/download?doi=10.1.1 .215 .20898 rep $=$ rep 18 type $=$ pdf

Zimmerman, B. J. (1990). Self-Regulated Learning and Academic Achievement: An Overview. Educational Psychologist, 25(1), 3-17. Retreived from https: / / ciel.viu.ca/sites/default/files / self_regulated_learni ng_and_academic_achievement_an_overview_0.pdf 